\title{
WITHIN-TREE VARIABILITY IN THE DRYING PROPERTIES FOR BLACKBUTT TIMBER IN NEW SOUTH WALES
}

\author{
S. J. Cabardo ${ }^{1}$, T. A. G. Langrish ${ }^{2}$
}

\begin{abstract}
The within-tree variability of drying properties, including the green and final moisture contents, the basic density, and the diffusion coefficient, has been investigated for regrowth blackbutt timber (Eucalyptus pilularis Sm).Timber boards from two regrowth trees were taken from Northern New South Wales in Australia, and dried in a lab scale kiln. The pattern of variation within the two trees was similar, such that the diffusion coefficient was strongly correlated with the initial moisture content and basic density. Principal components analysis suggested that the timber boards with low basic densities and high initial moisture contents had higher diffusion coefficients. A potential reason is that if there is less wood material per unit volume, then this leaves more space for water to occupy, and there is also less resistance for the diffusive transport of moisture. In addition, this suggested correlation was also evident in the analysis of variance (ANOVA).

A simulation study, using the timber data measured from the experiments in this paper, was also conducted to estimate how different hardwood drying schedules are likely to affect the distribution of the final moisture contents, and the time taken to reach an average stack moisture content of $0.15 \mathrm{~kg} /$ $\mathrm{kg}$. A revised version of the drying schedule used for the experiments in this paper, i.e. adding $5^{\circ} \mathrm{C}$ to the dry and wet-bulb temperatures, has been predicted to be a better drying schedule out of the four drying schedules studied, due to it drying the timber quicker as well as having a small dispersion of final moisture contents.
\end{abstract}

Keywords: diffusion, drying schedules, density, moisture content

\section{INTRODUCTION}

Australia produces close to 1 million cubic metres of sawn hardwood timber each year and imports another 142,000 cubic metres, of which more than 90\% comes from Indonesia and Malaysia (Caswell, 2005). It is predicted that 9.2 million cubic metres of logs per year will be harvested in the latter half of the present decade (Ferguson et al., 2002). In New South Wales alone, the consumption of eucalypts sawn wood was $263,000 \mathrm{~m}^{3}$ in 2000-01 (ABARE, 2001). Therefore, the less timber that is harvested locally, the more the country will have to rely on imports to meet increasing consumer demand. To reduce the importation of sawn timber from overseas, Australian timber drying companies may have to rely on getting most of their timber supplies from these hardwood plantations. However, timber companies report a growing difficulty in handling plantation timber for a number of reasons, one of which is the increased amount of variation in timber properties that can affect the dried quality of the timber. As a result, it is possible that large variations in intrinsic properties may require better control, hence optimized drying schedules that account for these variabilities may need to be developed.

Trial and error has been used for the development of kiln drying schedules in the past (Campbell, 1980; Mills, 1991). Subsequently, more rational approaches have been undertaken for the optimization of kiln drying schedules. Optimized kiln drying schedules have been developed from simulations (Cronin

\footnotetext{
${ }^{1,2}$ Department of Chemical Engineering, University of Sydney, Sydney, Australia 2006.

${ }^{1}$ E-mail: scabardo@chem.eng.usyd.edu.au.

${ }^{2}$ E-mail tim.langrish@usyd.edu.au

Corresponding author: scabardo@chem.eng.usyd.edu.au

Received: November 04, 2005. Accepted: March 26, 2006.
} 
et al., 2003) that have considered the variability of final moisture contents. Continuous kiln drying schedules (Booker, 1994; Alexiou, 1993; Langrish et al., 1997) have also accounted for stress, strain, and checking/cracking. Pordage and Langrish (2000) developed a method for generating kiln drying schedules that considered the variability of timber properties, using very limited data on variability from Doe and Innes (1999). In addition, the variability of the biological parameters was assumed by Pordage and Langrish (2000) to be normally distributed, and the parameters were assumed to be uncorrelated with one another. Kayihan (1993) also assumed that there was no correlation between the green moisture content and the drying-rate parameters. Siau (1984) suggested that the variability in the green moisture content may be correlated with the variability in the timber density but this hypothesis has yet to be confirmed. Overall, there is little information about the variability in timber properties with respect to drying, including how strongly they are correlated. The remaining challenges in optimizing kiln drying schedules thus include getting sufficient data on the variability of timber properties, and carrying out the optimization both to minimize cracking and to minimize the dispersion of final moisture contents.

The tree species chosen for this study was blackbutt (E.pilularis), because blackbutt is the predominant planted hardwood species in NSW, Australia (Boland et al., 1989) and is considered to be one of the most important eucalypts for planting in NSW (Johnson and Nikles, 1996).

Since the amount of variability is a key issue in the processing of timber, the variation of diffusion coefficients, basic densities, and green and final moisture contents for regrowth blackbutt, has been investigated in this paper. These investigations have been followed by a simulation study of the effects of different drying schedules on 12 blackbutt boards used in the experiments.

\section{MATERIALS AND METHODS}

\section{Preparation of Samples}

Blackbutt boards, $28 \mathrm{~mm}$ thick x $108 \mathrm{~mm}$ wide x $900 \mathrm{~mm}$ long, were cut from two regrowth logs (Log 1 and $\log 2$ ). Each $\log$ was approximately $4.8 \mathrm{~m}$ in length. The boards were taken from different locations within each log, as shown in Figures 1 and 2. Each ' $A$ ' board has its corresponding ' $E$ ' board that was taken from the top end of each log. The boards were wrapped in thick polythene film until further processing. Thereafter, a $20 \mathrm{~mm}$ thick sample was taken from each end of each green ' $\mathrm{A}$ ' and ' $E$ ' board to calculate its corresponding initial moisture content using the oven-dry method. The final length of each green timber board was $800 \mathrm{~mm}$ after the moisture content, the green modulus of elasticity (MOE) and the shrinkage samples were taken. However, the results for the green MOE and shrinkage tests are not shown in this paper. The remaining board length was end-sealed using silicone and aluminum foil. Thereafter, the timber boards were kiln dried in a drying tunnel, using the conventional drying schedule published in the Australian Timber Seasoning manual (Mills, 1991) suited for mixed sawn blackbutt boards, $25 \mathrm{~mm}$ in thickness, shown in Table 1 .

Each kiln charge consisted of six boards. One board was taken from close to the pith, another board was taken from close to the bark, and another board was taken at a certain circumferential distance from the two boards. The remaining three boards were at the same radial and circumferential distances but at the other end of the log. This procedure was followed for the first four drying experiments. The fifth kiln charge consisted of 12 boards (equivalent to two previous experiments) to increase the amount of data gathered per experiment. The boards were stacked on top of each other, separated by stickers, with the schedule changed on the basis of the day number. Each experiment took 21 days to run. The final moisture contents were calculated by cutting another $20 \mathrm{~mm}$ sample from each board at the end of the drying process, and repeating an oven-dry test. The actual moisture contents of each board were calculated daily by weighing of the individual boards. The boards were rotated within the 
kiln stack, on a daily basis, to minimise stacking effects on drying. Timber density was based on the oven-dry weight/green volume, where the original sample dimensions were measured for the calculation of the green volume.

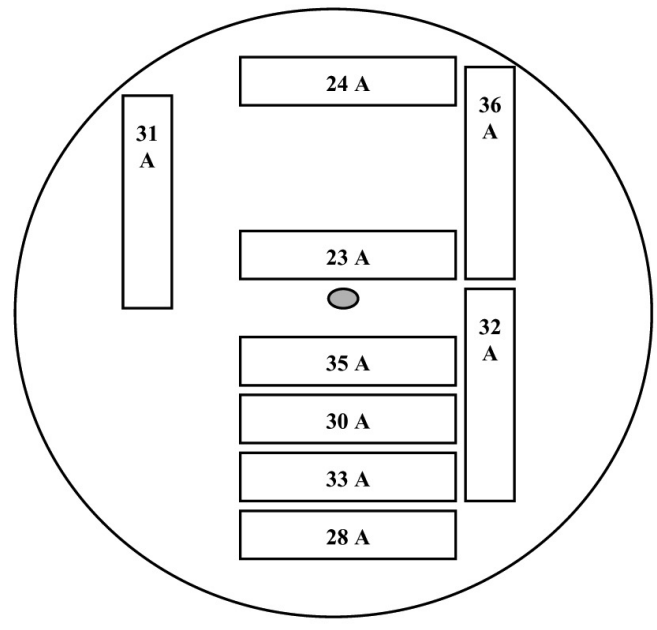

FIGURE 1. Cross-section of the bottom end of $\log 685$, showing where each 'A' board was taken.

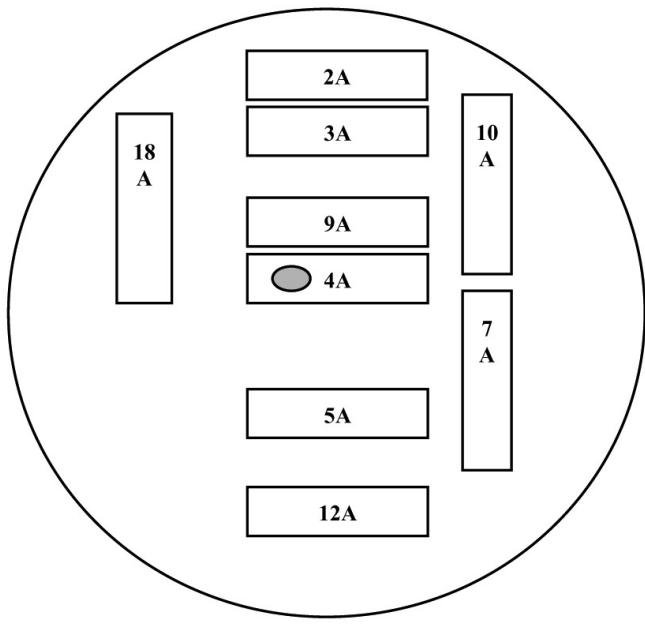

FIGURE 2. Cross-section of the bottom end of $\log 686$, showing where each 'A' board was taken.

Table 1. Drying schedule used for all experiments (Mills, 1991).

\begin{tabular}{|l|c|c|c|c|c|c|}
\hline Day to Carry Out Change Point & $\mathbf{0}$ & $\mathbf{5}$ & $\mathbf{8}$ & $\mathbf{1 0}$ & $\mathbf{1 2}$ & $\mathbf{1 5}$ \\
\hline $\begin{array}{l}\text { Estimated Moisture Content at Change } \\
\text { Points (\%) }\end{array}$ & Green & $\mathbf{4 0}$ & $\mathbf{3 0}$ & $\mathbf{2 5}$ & $\mathbf{2 0}$ & $\begin{array}{c}\mathbf{1 5} \text { to final } \\
\text { (usually } \\
\mathbf{1 2}\end{array}$ \\
\hline Dry Bulb Temperature $\left({ }^{\mathbf{0}} \mathbf{C}\right)$ & 55 & 60 & 65 & 65 & 70 & 70 \\
\hline Wet Bulb Depression $\left({ }^{\mathbf{0}} \mathbf{C}\right)$ & 3 & 4 & 5 & 8 & 10 & 15 \\
\hline
\end{tabular}

\section{Drying Tunnel}

Figure 3 shows the overall design of the pilot-scale batch dryer used for drying $800 \mathrm{~mm}$ timber boards. This conventional kiln was used to produce controlled drying conditions, with initial dry-bulb and wet-bulb temperatures of $55^{\circ} \mathrm{C}$ and $52^{\circ} \mathrm{C}$ (Table 1), respectively, and an air velocity of $1.3 \mathrm{~m} / \mathrm{s}$ across the flat surfaces of the boards. Manipulating the steam flowrate to a steam-injection system was used to control the wet-bulb temperature to its desired setpoint. The steam-injection system consisted of a dryer and six-point steam injection pipe over a $300 \mathrm{~mm}$ duct. The control mechanism for the drybulb temperature involved the flowrate adjustment of $100 \mathrm{kPa}$ (gauge) steam to a finned heat exchanger using a control valve. The overall size of the kiln working section has a volumetric capacity of 0.162 $\mathrm{m}^{3}$, a height of $0.45 \mathrm{~m}$, a stream-wise length of $0.4 \mathrm{~m}$, and a cross-stream width of $0.9 \mathrm{~m}$. The mass of each board was measured and used to calculate the average moisture content of each board on a daily basis. An overall mean of these averages was then used to determine if the set points of the dry-bulb and wet-bulb temperatures had to be altered according to the drying schedules shown in Table 1 . Overall, each experiment had the same change over times. 


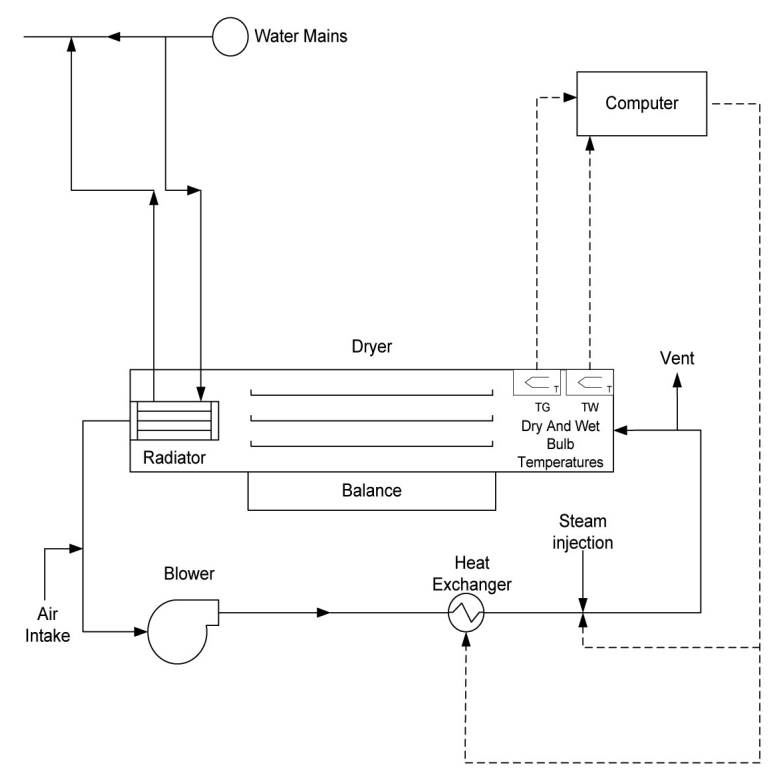

FIGURE 3. Schematic diagram of timber drying tunnel.

\section{Fitting Procedure for Diffusion Coefficients}

The predicted overall drying curve is dependent on the diffusion coefficients and operating temperatures for each experiment (Langrish et al., 1997). The model is based on solving Fick's Second Law of diffusion for mass transfer and Fourier's Law for heat transfer. The equations used for the mass transfer and heat transfer of the timber boards were based on the equations used by Langrish et al. (1997). Moisture is assumed to diffuse through the timber and evaporate near the surface. It is often difficult to measure the diffusion coefficient directly, but it can be fitted to experimental data, as here. Schaffner (1981) and Wu (1989) both successfully fitted diffusion coefficients to observed data for eucalypt timbers. Therefore, leastsquares parameter fitting was used to adjust the value of the reference diffusion coefficient, $D_{r}$ in an Arrheniustype equation:

$$
D=D_{r} \exp \left(-D_{E} / T\right)
$$

The parameter fitting minimizes the sum of squares of the difference between the predicted and actual average moisture contents for each board. A typical initial value of $D_{r}$ was $0.6 \times 10^{-5} \mathrm{~m}^{2} \mathrm{~s}^{-1} . D_{E}$, in units of Kelvin, represents the $E / R$ in the exponent term (where $E$ is the activation energy in $\mathrm{J} / \mathrm{mol}$, and $R$ is the gas constant, $8.314 \mathrm{~J} / \mathrm{mol} . \mathrm{K}$ ) since it represents the temperature dependence of moisture diffusion (Keey et al., 2000). The value of $D_{E}$ used in this simulation was $3800 \mathrm{~K}$ because this value was also used by Wu (1989) and Schaffner (1981) in their simulations of Tasmanian eucalypts. In addition, Haque (2002) used the value of $3800 \mathrm{~K}$ for $D_{E}$ for his drying simulation of blackbutt, which is the same species studied in this paper. When calculating each of the timber board's respective diffusion coefficients, $D$, using Equation $(1), 60^{\circ} \mathrm{C}$ $(333 \mathrm{~K})$ was used for the temperature value, $T$, to represent the temperature of each board, as an average, during the whole drying process.

The recorded moisture contents that were measured throughout the drying process, and the dry and wetbulb temperatures, depended on each board and each experiment. The fitted initial moisture content was set equal to the actual initial moisture content. Fick's Second Law of diffusion for mass transfer and the conduction equation for heat transfer were then solved simultaneously, with convective boundary conditions at the board surfaces and symmetry at the centerline of each board. Overall, the final adjusted value of $D_{r}$ 
characterized the drying behaviour of the corresponding timber board, and along with the $D_{E}$ value of 3800 $\mathrm{K}$ and $60^{\circ} \mathrm{C}$ as the value for $T$, the individual board's diffusion coefficient, $D$, was calculated.

\section{RESULTS AND DISCUSSION}

\section{Drying Properties and Analysis of Variance (ANOVA)}

The fitting procedure fitted the drying behaviour over $95 \%$ of the cases within experimental uncertainties when comparing the measured and the predicted average moisture content. The range of the diffusion coefficients, the initial and final moisture contents, and the basic densities, are shown in Table 2. The initial moisture contents decreased from pith to bark, and the basic densities increased from pith to bark. Preliminary ANOVAs were performed on each log separately with a 75\% confidence level (with 12 boards representing each log). The preliminary ANOVA showed that circumferential and radial effects were significant sources of the within-tree variation for the diffusion coefficients, the initial moisture contents and the basic densities. No effects were significant for the variation of the final moisture contents within trees. Moreover, the results for the initial moisture contents and basic densities agreed with the work reviewed by Walker (1993) regarding hardwoods such as Yellow Birch, American Beech, and Shining Gum. He observed the same behaviour within a single tree, i.e. initial moisture contents and basic densities varied from pith to bark. In addition, Wimmer (2000) observed an increase in basic density and a decrease in moisture content from pith to bark for softwoods, similar to our results with hardwoods. Walker (1993) also suggested that wood material with low basic density had a high initial moisture content and vice versa. Wood with a low basic density has a considerable volume of void space that water can fill when the timber is green, because the low basic density means a small volume of wood material in the cell walls. Furthermore, the ANOVA showed that the height effect (except for initial moisture content) is not a significant source of variation for the basic densities and the diffusion coefficients. For this work, an ANOVA using 18 boards from each log was also conducted, and the results emphasise that only radial effects were likely to be significant sources of variation for the diffusion coefficient. Overall, these results support the previous suggestion that the behaviour of these three parameters changes across the radius of the log.

Table 2. Timber properties for blackbutt timber (thirty-six boards).

\begin{tabular}{|l|c|c|}
\hline \multicolumn{1}{|c|}{ Timber Property } & Minimum & Maximum \\
\hline $\begin{array}{l}\text { Diffusion Coefficient, } \\
D\left(\times 10^{-10} \mathrm{~m}^{2} \mathrm{~s}^{-1}\right)\end{array}$ & 1.14 & 4.53 \\
\hline Basic Density $\left(\mathrm{kg} \mathrm{m}^{-3}\right)$ & 356 & 934 \\
\hline Initial Moisture Content $(\mathrm{kg} / \mathrm{kg})$ & 0.46 & 1.13 \\
\hline Final Moisture Content $(\mathrm{kg} / \mathrm{kg})$ & 0.08 & 0.18 \\
\hline
\end{tabular}

\section{Principal Components Analysis}

A correlation between high initial moisture contents, higher diffusion coefficients, and low basic densities was observed with the measured and calculated drying properties. The timber boards with higher densities had more wood material per unit volume. This may either be due to large cell volumes and/or more cell-wall material, leaving less space for water to occupy, which explains the low initial moisture contents for timber boards with high densities (Keey et al., 2000; Walker, 1993). In addition, more wood material means a higher resistance to diffusive transport of moisture (Keey et al., 2000). Therefore the diffusion coefficient is expected to be low in high density wood. A principal component analysis (PCA) (Smith, 2002) was performed on the three parameters. If these parameters are closely correlated, then the PCA should result in only one large principal component, and one large eigenvalue and eigenvector (Smith, 2002; Britton et al., 1999). The results of the PCA showed that the first and largest eigenvalue accounted for $96 \%$ of the total amount of variation within these parameters, shown in Figure 4, giving some evidence in support of the above-mentioned 
correlation between the parameters. The strong correlation between the diffusion coefficient, $D$, and the initial moisture content, $X_{i}$ (and basic density) is represented by Equation (2):

$$
D=\left(6 \times 10^{-10}\right) X_{i}-\left(2 \times 10^{-10}\right)
$$

Figure 4 shows that boards with high initial moisture contents have low basic densities, and thus high diffusion coefficients. One board from $\log 1$ had a high basic density, but had a high diffusion rate; possibly due to the crack present throughout the length of the board.

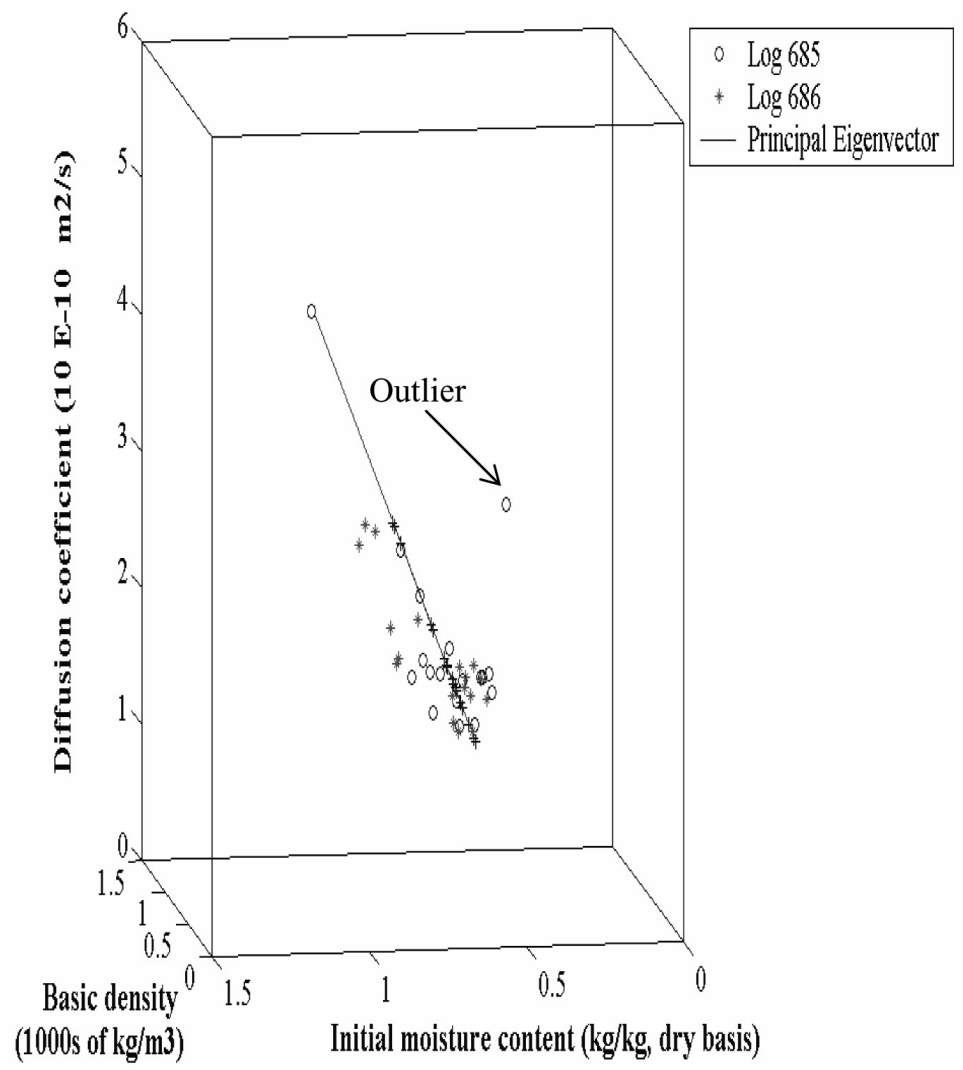

FIGURE 4. Three-dimensional plot of the parameters from Principal Components Analysis, together with the principal eigenvector.

\section{Comparing the Effects of Different Drying Schedules}

The effects of different drying schedules and the measured variabilities of initial moisture contents and diffusion coefficients on the variability of final moisture contents, when the average moisture content within a stack of timber reached $15 \%$, were predicted by using the same drying model. Tables 3 to 5 show the drying schedules used for this comparison. These drying schedules were used by Kärki (2002), whose experiment dried European aspen (hardwood), Innes and Redman (2003) to model the drying of six different regrowth hardwoods including blackbutt, and for this study, a revised drying schedule by adding $5^{\circ} \mathrm{C}$ to the dry and wet-bulb temperatures to the drying schedule in Table 1 . The results from these drying schedules have then been compared, in terms of the dispersion of the final moisture contents, with the drying schedule used for the experiment in this paper (Table 1). The data used with the 12 timber boards chosen for this simulation were the boards with the highest and lowest initial moisture contents from each drying experiment. 
Table 3. Drying schedule used by Kärki (2002) to dry European aspen.

\begin{tabular}{|c|c|c|}
\hline Time (hours) & Dry-Bulb Temperature $\left(\mathbf{C}^{\mathbf{C}}\right)$ & Wet-Bulb Temperature $\left.\mathbf{(}^{\mathbf{}} \mathbf{C}\right)$ \\
\hline 0 & 20 & 18 \\
\hline 20 & 50 & 47 \\
\hline 40 & 50 & 46 \\
\hline 60 & 50 & 45 \\
\hline 80 & 55 & 47 \\
\hline 100 & 60 & 49 \\
\hline 120 & 65 & 50 \\
\hline 140 & 70 & 52 \\
\hline 160 & 70 & 52 \\
\hline 180 & 55 & 50 \\
\hline
\end{tabular}

Table 4. Drying schedule used by Innes and Redman (2003) to dry blackbutt timber.

\begin{tabular}{|c|c|c|}
\hline Time (hours) & Dry-Bulb Temperature $\left({ }^{\mathbf{C}} \mathbf{C}\right)$ & Wet-Bulb Temperature $\left({ }^{\mathbf{C}} \mathbf{C}\right)$ \\
\hline 0 & 23 & 21.5 \\
\hline 168 & 23 & 21 \\
\hline 336 & 24 & 21.5 \\
\hline 504 & 24 & 21 \\
\hline 840 & 25 & 20.5 \\
\hline 1008 & 25 & 20 \\
\hline
\end{tabular}

Table 5. Revised drying schedule, for this study, by using the drying schedule from Mills (1991) to dry $25 \mathrm{~mm}$ thick blackbutt timber and adding $5^{\circ} \mathrm{C}$ to the temperatures.

\begin{tabular}{|c|c|c|}
\hline Time (hours) & Dry-Bulb Temperature $\left({ }^{\mathbf{0}} \mathbf{C}\right)$ & Wet-Bulb Temperature $\left({ }^{\mathbf{0}} \mathbf{C}\right)$ \\
\hline 0 & 60 & 57 \\
\hline 120 & 65 & 61 \\
\hline 192 & 70 & 65 \\
\hline 240 & 70 & 62 \\
\hline 288 & 75 & 65 \\
\hline 360 & 75 & 60 \\
\hline
\end{tabular}

Table 6. Statistical analysis of the predicted final moisture contents using the different drying schedules.

\begin{tabular}{|l|c|c|c|c|}
\hline \multirow{2}{*}{$\begin{array}{c}\text { Drying } \\
\text { Schedule Used }\end{array}$} & \multirow{2}{*}{$\begin{array}{c}\text { Time } \\
\text { (hours) }\end{array}$} & \multicolumn{3}{|c|}{ Final Moisture Content (kg/kg) } \\
\cline { 3 - 5 } & Average & $\begin{array}{c}\text { Standard } \\
\text { Deviation }\end{array}$ & $\begin{array}{c}\text { Coefficient of } \\
\text { Variation }\end{array}$ \\
\hline $\begin{array}{l}\text { 1.Original drying } \\
\text { schedule }\end{array}$ & 396 & 0.15 & 0.013 & 0.087 \\
\hline 2.Kärki (2002) & 255 & 0.15 & 0.029 & 0.193 \\
\hline $\begin{array}{l}\text { 3.Innes and } \\
\text { Redman (2003) }\end{array}$ & 1386 & 0.15 & 0.014 & 0.093 \\
\hline $\begin{array}{l}\text { 4.Original drying } \\
\text { schedule }+5^{\circ} \mathrm{C}\end{array}$ & 378 & 0.15 & 0.013 & 0.087 \\
\hline
\end{tabular}

Table 6 shows the different effects of each drying schedule on the time that it takes for the timber stack to reach an average moisture content of $0.15 \mathrm{~kg} / \mathrm{kg}$, and the dispersion of final moisture contents. These results show a trade off between the shortness of the drying schedule and the dispersion of final moisture contents. Drying schedule 2 gave the shortest time for the stack of timber to reach the target average moisture 
content, but its conditions produced the largest dispersion of final moisture contents. Drying schedule 3 gave the longest drying time, but the dispersion of final moisture contents was two times smaller $(0.093)$ compared with the dispersion of final moisture contents from drying schedule number 2 (0.193). On the other hand, the conditions of drying schedules 1 and 4 seem to be similar in terms of the distribution of final moisture contents. However, increasing all the temperatures in drying schedule 1 by $5^{\circ} \mathrm{C}$ (drying schedule 4) reduced the drying time. Elevated temperatures increase the diffusion coefficient and hence the drying rate, decreasing the drying time.

There are limitations, however, associated when using high temperatures in kiln drying. Collapse is an abnormal shrinkage in the timber at moisture contents above the fibre saturation point during drying, and many Australian eucalypt timbers are prone to collapse (Chafe et al., 1992; Innes, 1996). Innes (1995) used a stress-strain model to assess the stress and strain distributions within the fibre cell walls of Tasmanian eucalypt and found that the stresses and strains in the fibre cell wall were sensitive to small variations in temperature. In another study comparing three drying strategies aimed to avoid collapse checking for Tasmanian eucalypt, Innes (1996) suggested there was a "collapse threshold" temperature for any timber specimen, above which collapse was likely to be severe. In addition, due to reactions involving some constituents in the wood along with the combined effect of high temperature and relative humidity (MTC, 2002), sometimes discolouration of the timber occurs when kiln drying. The discolouration of the timber may become unacceptable, especially for appearance grade products (AS/NZS 4787:2001). McCurdy et al. (2003) reported that high drying temperatures (as high as $120^{\circ} \mathrm{C}$ ) enhanced the darkening of Pinus radiata sapwood boards and thus, both temperature and drying time were significant factors for timber discolouration during drying.

In general, from this study, it may be possible to develop a drying schedule that increases the productivity of timber, i.e. amount of good quality timber divided by the drying time, (Pordage and Langrish, 2000) by accounting for biological variability and considering the mentioned limitations (which were stress and strain constraints, and the maximum temperatures that can be reached before collapse and discolouration occurs). This development can be done by using the data for this variability in the diffusion coefficients, the initial moisture contents, and the basic densities measured in this work, and the shrinkage coefficients (which are not reported in this paper).

\section{CONCLUSIONS}

Within a tree, the initial moisture contents decreased from pith to bark, and the basic densities increased from pith to bark. A correlation between the initial moisture content, the basic density, and the diffusion coefficient, using Principal Components Analysis (PCA), was observed from each board. Timber boards with high initial moisture contents had low basic densities and high diffusion coefficients. This observation may be connected with the link between less wood material, more space for water in the green timber, and the increased ease with which moisture can diffuse through the timber board.

Different drying schedules affected the time taken to reach an average stack moisture content of $15 \%$, and the distribution of final moisture contents of the 12 timber boards. The drying schedule that was also used for the experiments, and the revised version of the same schedule, were similar in terms of the dispersion of final moisture contents, but the latter producing a shorter drying time. Overall, from this simulation study, the presence of variability in the timber properties implicitly affects the drying rate and the dispersion of final moisture contents by the choice of the drying schedule used.

\section{ACKNOWLEDGEMENTS}

This work is supported by the Australian Research Council, Forests NSW- a special mention to Dr. Ross Dickson and Mr. Bill Joe, and J. Notaras and Sons, Grafton. The authors are very grateful for their support and help for this project. 


\section{REFERENCES}

ABARE. 2001. Australian Forest and Wood Products Statistics, March and June quarters 2001. ABARE, Canberra, p. 13.

Alexiou, P.N. 1993. Accelerated Kiln-Drying and Drying Stresses in Regrowth Blackbutt Eucalyptus Pilularis Sm. M. Sci. Thesis, Australian National University, Australia, pp. 31-44, 57-75.

Australian/New Zealand Standard ${ }^{\text {TM }}$ AS/NZS 4787:2001. Timber - Assessment of Drying Quality, Standards Australia, Standards New Zealand, accessed March 12, 2003.

Boland, D.J.; Booker, M.I.H.; Chippendale, G.M.; Hall, N.; Hyland, B.P.M.; Johnston, R.D.; Kleinig, D.A.; Turner, J.D. 1989. Forest Trees of Australia, CSIRO Melbourne.http://data.brs.gov.au/ mapserv/plant/species.php?speciesid=14, accessed November 24, 2003.

Booker, J. 1994. Improved Hardwood Timber Seasoning Productivity. PhD Thesis, Faculty of Engineering, University of Tasmania, Australia, pp. iv-ix, 46-64, 116-126.

Britton, S.C.; Coleman. C.E.; Henderson, J. 1999. The Little Blue Book. School of Mathematics and Statistics, University of Sydney, pp. 60-62.

Campbell, G.S. 1980. Index of Kiln Drying Schedules for Timber Dried in Australia. Commonwealth Scientific and Industrial Research Organisation Building Research Division.

Caswell, T. 2005. Native Forestry is a way for wood. The Australian Newspaper, March 21, 2005, p. 30.

Chafe, S.C.; Barnacle, J.E.; Hunter, A.J.; Ilic, J.; Northway, R.L.; Rozsa, A.N. 1992. Collapse: An Introduction. CSIRO Division of Forest Products, Melbourne, Australia.

Cronin, K.; Baucour, P.; Abodayeh, K.; Barbot Da Silva., A. 2003. Probabilistic Analysis of Timber Drying Schedules. Drying Technology 21(8): 1433-1456.

Doe, P.E; Innes, T.C. 1999. Seasonability Determination from In-Log Property Measurements. Proceedings Sixth IUFRO International Wood Drying Conference, Stellenbosch, South Africa, pp. 117120.

Doe, P.E.; Oliver, A.R.; Booker, J.D. 1994. A Non-Linear Strain and Moisture Content Model of Variable Hardwood Drying Schedules. Proceedings Fourth IUFRO International Wood Drying Conference, Rotorua, New Zealand, pp.203-210.

Ferguson, I.S.; Fox, J.; Baker, T.; Stackpole, D.; Wild, I. 2002. National and Regional Plantation Wood Availability 2001-2044. Consultant's Report for National Forest Inventory, Bureau of Rural Sciences, Canberra.

Haque, N. 2002. Modelling of Solar Kilns and the Development of an Optimised Schedule for Drying Hardwood Timber. PhD Thesis. The University of Sydney, Australia, pp. 78-79, 158.

Innes, T.C. 1995. Stress Model of a Wood Fibre in Relation to Collapse. Wood Science and Technology 29: 363-376.

Innes, T.C. 1996. Pre-drying of Collapse Prone Wood Free of Surface and Internal Checking. Holz als Roh- und Werkstoff 54: 195-199. 
Innes, T.C.; Redman, A.L. 2003. Comparative Drying Characteristics of Six Regrowth Australian Hardwoods, Proceedings Eight International IUFRO Wood Drying Conference, Brasov, Romania, Aug 2429; International Union of Forest Research Organizations; 101-105.

Johnson, I.G. and Nikles, D.G. 1996. Plan for Developing and Deploying Genetically- Improved Varieties of Blackbutt (E.pilularis Smith) in NSW. State Forests of New South Wales Technical Paper, Number 63, pp. 1-5.

Kärki, T. 2002. Drying Quality of European Aspen (Populus tremula) Timber. Holz als Roh- und Werkstoff 60: 369-371.

Kayihan, F. 1993. Adaptive Control of Stochastic Batch Lumber Kilns. Computers and Chemical Engineering 17(3): 265-273.

Keey, R.B.; Langrish. T.A.G.; Walker, J.C.F. 2000. Kiln Drying of Lumber. Springer Verlag, Berlin, pp. 65-115, 175-181.

Langrish, T.A.G.; Brooke, A.S.; Davis, C.L., Musch, H.E; Barton, G.W. 1997. An Improved Drying Schedule for Australian Ironbark Timber: Optimization and Experimental Validation. Drying Technology 15(1): 47-70.

Malaysian Timber Council (MTC). 2002. Staining and Discolouration. http://www.mtc.com.my/ publication/library/drying/ch46.htm, accessed May 4, 2005.

McCurdy, M.; Pang, S.; Keey, R. 2003. Measurements of Colour Development in Pinus radiata Sapwood Boards During Drying at Various Schedules, Proceedings Eight International IUFRO Wood Drying Conference, Brasov, Romania, Aug 24-29; International Union of Forest Research Organizations; 445-449.

Mills, R. 1991. Australian Timber Seasoning Manual. Australian Furniture Research and Development Institute Limited, pp. 160-166.

Pordage, L.J.; Langrish, T.A.G. 2000. Optimization of Hardwood Drying Schedules Allowing for Biological Variability. Drying Technology 18(8): 1797-1815.

Schaffner, R.D. 1981. Fundamental Aspects of Timber Seasoning, M.Eng.Sci. Thesis, Faculty of Engineering Science, Faculty of Engineering, University of Tasmania, Australia, pp. 130-135.

Siau, J.F. 1984. Transport Processes in Wood. Springer Verlag, New York, p. 25.

Smith, L.I. 2002. A Tutorial on Principal Components Analysis.http://www.cs.otago.ac.nz/cosc453/ student_tutorials/principal_components.pdf, accessed March 19, 2004.

Walker, J.C.F. 1993. Primary Wood Processing. Chapman \& Hall, London, pp. 68-74.

Wimmer, R. 2000. Wood Quality - Causes, Methods, Control.http://www.boku.ac.at/botanik/wood/ woodquality/Chapter4.pdf, accessed August 15, 2003.

Wu, Q. 1989. An Investigation of Some Problems in Drying of Tasmanian Eucalypt Timbers. M.Eng.Sci. Thesis, University of Tasmania, Hobart, pp. 140-141 